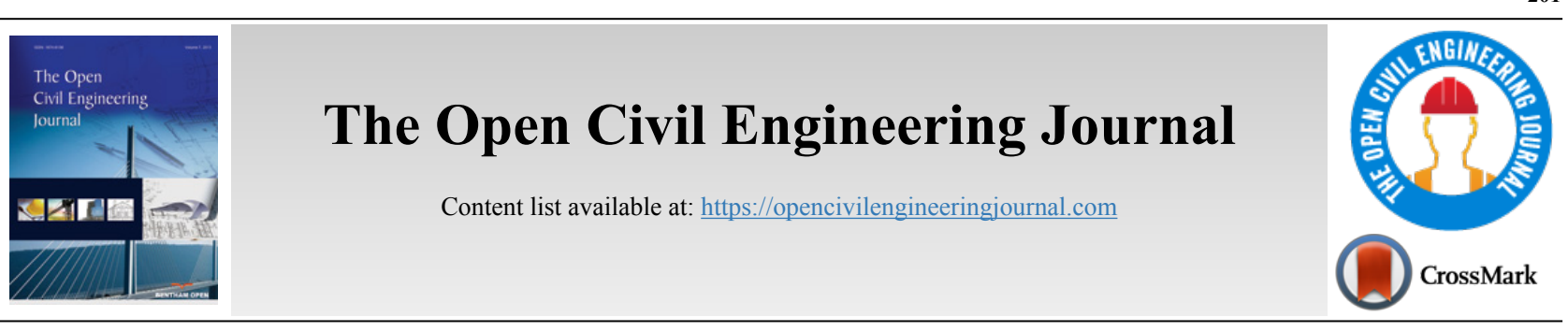

RESEARCH ARTICLE

\title{
Evaluation of Concrete Quality for Reinforced Concrete Frame Members Exposed to Natural Fires at Early Ages Using in situ Test Methods
}

\author{
Muhammad I. Omer ${ }^{1, *}$ and Dilshad K. Jaf ${ }^{1}$ \\ ${ }^{\prime}$ Department of Civil Engineering, Salahaddin University, Erbil, Iraq
}

\begin{abstract}
:
Background:

In recent years, numerous reinforced concrete buildings have been constructed in Iraq and some developing countries. Fire accidents occur in wooden formwork especially during the summer season due to problems associated with the construction procedure and on-site management. And fires can erupt during the construction stage of buildings.

Introduction:

Generally, if fire accidents occur in a wooden formwork, in these situations the concrete in the field is at an early age (i.e., "young"). The internal structure and chemical composition of early-age concrete are different from that of the carrier due to incomplete hydration at an early age. This study aimed to evaluate the strength of reinforced concrete frames at early ages when exposed to natural fire. The evaluation of existing buildings is an important issue that involves researchers and engineers in many countries.

\section{Methods:}

The experimental program consisted of constructing three full-scale reinforced concrete frames that are then exposed to natural fire. When the concrete age reaches three and five days by firing its formwork, the concrete quality of the structure was evaluated via ultrasonic pulse velocity as a nondestructive measurement. Core test was used as a destructive technique to implement a relationship between compressive strength and nondestructive measurements.

Results:

The results showed that the frame exposed to natural fire early was generally more affected than the other frame, and its compressive strength was reduced close to $33 \%$. The results also showed that the ultrasonic pulse velocity test for the structural elements was smaller than those of the core test.

Conclusion:

It can be concluded that the current assessment methodology must be evaluated to provide practical suggestions that can enhance the reliability of assessing the in situ strength of existing concrete structures by nondestructive tests and cores.
\end{abstract}

Keywords: Evaluation, Concrete quality, Reinforced concrete structures, Natural fire, Early ages, In situ test methods.

Article History Received: August 30, 2019 Revised: October 15, 2019 Accepted: November 2, 2019

\section{INTRODUCTION}

Reinforced concrete is commonly used in the structural system in Iraq and all over the world [1]. In Iraq, timber is commonly used in molding formwork of reinforced concrete structures. Wood is a well-known and easily combustible mate-

\footnotetext{
* Address correspondence to this author at Department of Civil Engineering, Salahaddin University, Erbil, Iraq; Tel: 009647504521812;
}

E-mail: muhammad.omer@su.edu.krd rial if it is oiled, especially during the summer season. Therefore, in recent years, numerous reinforced concrete buildings have been constructed in Iraq and some developing countries. Fire accidents occur due to problems with the construction procedure and on-site management, and fires can occur during the construction stage of buildings [2]. Generally, in these situations, the concrete in the field is at an early age (i.e., "young"). Since the concept of early age is still unclear in the field of concrete materials, the term 'early age' is used to 
describe concrete that is one week or less of age [3]. The internal structure and chemical composition of early-age concrete are different from those in the carrier due to incomplete hydration at an early age.

General reviews of concrete behavior at a high temperature can be found in the literature [4 - 6]. Extant research has shown that concrete is a versatile material and can act as inherently fire-resistant if designed appropriately. The response of concrete material and structure to a real fire depends on the nature of the fire, which can vary considerably. Moreover, the gas temperature will change throughout the fire compartment [7].

Bisby et al. (2013) reviewed the results of large-scale nonstandard structures that were subjected to specific fire tests. They found that nonstandard fire tests conducted around the world in the past three decades revealed numerous weaknesses in our understanding of real fires; in most cases, these shortcomings could not have been detected through standard furnace tests [8].

Fire causes heat to flow into the concrete structure. The temperature in the concrete mass will rise, thereby causing thermal expansion of the constituents, evaporation of moisture, the buildup of pore pressure, and the degradation of mechanical properties [7]. The deterioration of concrete strength due to short-term exposure to elevated temperature (fire) attracted attention in the last decades. The nature of the fire, types of structure, and loading system are reasons that the modes of concrete failure under fire exposure will be varied [1].

Temperatures below $200{ }^{\circ} \mathrm{C}$ do not significantly impact the mechanical properties of concrete, especially compressive strength. However, these low temperatures will affect the external layer of concrete and introduce necessary changes within the durability of the material [9].

When concrete is exposed to high temperatures, its chemical composition and physical structure are modified significantly, thereby leading to a significant reduction of mechanical properties, such as strength, modulus of elasticity, and volume stability [10]. When the temperature reaches about $300{ }^{\circ} \mathrm{C}$, some of the combined water from $\mathrm{C}-\mathrm{S}-\mathrm{H}$ and sulfoaluminate hydrates and the interlayer calcium silicate hydrate $(\mathrm{C}-\mathrm{S}-\mathrm{H})$ water will evaporate. Calcium hydroxide $\left(\mathrm{Ca}(\mathrm{OH})_{2}\right)$, which is one of the most essential compounds in cement paste, dissociates at around $530{ }^{\circ} \mathrm{C}$, thereby resulting in the shrinkage of concrete [11].

Given the actual building, fire conditions are different from those in the ASTM E119 [12] test, an assembly with a 2-hr rating will not necessarily survive a real fire for $2 \mathrm{hrs}$. The ASTM E119 [12] test is a suitable method for rating the relative fire resistance of different building elements, but it is not a good predictor of the elements' actual duration in a real fire. A real fire is characterized by three phases, unlike the standard fire curve: a growing phase, a fully developed phase, and a phase of decay. In several institutions, many isolated member tests have been performed over the years. Research involving full-scale tests under natural fire, however, is limited [13].

Although severe fire may significantly damage reinforced concrete structures, the collapse of reinforced concrete structures as a result of fire damage rarely happens. Therefore, if a fire accident occurs during the construction period, then structural engineers should assess the residual strengths of younger reinforced concrete structural members to evaluate the safety and repairability of that building after the fire [2].

The evaluation of existing buildings is an important issue that involves researchers and engineers in many countries [14]. One of the successful techniques for evaluating chemical and physical changes and damage in concrete after a fire is the use of nondestructive testing methods. Most in situ techniques are known and extensively used for assessing concrete conditions after exposure to fire [15 - 17]. Although several methods are used to estimate the quality of concrete in structures, problems are generally solved by drilling and testing core specimens from the structural member [18]. The core test is expensive, but it is the most useful and reliable way to assess the properties of in-place concrete because it mechanically tests the cores after destruction [18].

The Ultrasonic Pulse Velocity (UPV) method was used in this study to establish the relationship between compressive strength and the UPV propagation when concrete was exposed to elevated temperatures. Almost no relevant study within the technical literature is available. However, these early-age concretes once exposed to high temperatures. Thus, an experimental study on the strength properties of early-age concrete after exposure to high temperature was performed. However, the effect of removing the formwork was identified by firing the wood on reinforced concrete frames at an early age.

\section{MATERIALS AND METHODS}

\subsection{Materials}

Three reinforced concrete frames were constructed using cement, water, fine aggregate, coarse aggregate. The following is a brief description of the material used throughout the study.

\subsubsection{Cement}

The cement used was ordinary Portland cement/Lafarge OPC. Its physical properties and chemical composition are given in Table $\mathbf{1}$ and Table $\mathbf{2}$, respectively. The results indicate that the cement conforms to ASTM-C150, 2007.

\subsubsection{Aggregate}

Locally available natural sand from local quarries was used as fine aggregate. The coarse aggregate used was the locally available crushed limestone aggregated gravel, with a maximum size of $9.5 \mathrm{~mm}$. The sand and gravel were graded according to (ASTM-C33, 2007), limits are listed in Table $\mathbf{3}$ and Table 4.

\subsubsection{Mix proportion}

The mix proportion used in fabricating reinforced concrete frames is presented in Table $\mathbf{5}$. 
Table 1. The physical test of cement.

\begin{tabular}{|c|c|c|c|c|c|}
\hline \multicolumn{2}{|l|}{ Type of Test } & \multirow{2}{*}{\begin{tabular}{|l|} 
Unit \\
$\min$ \\
\end{tabular}} & \multirow{2}{*}{\begin{tabular}{|l|} 
Result \\
180 \\
\end{tabular}} & \multirow{2}{*}{\begin{tabular}{|l|}
$\begin{array}{l}\text { Specification } \\
\text { Limits }\end{array}$ \\
$\geq 45$ \\
\end{tabular}} & \multirow{3}{*}{\begin{tabular}{|l|}
$\begin{array}{l}\text { Evaluation } \\
\text { specification }\end{array}$ \\
ASTM \\
C191-04 \& \\
C187-04
\end{tabular}} \\
\hline $\begin{array}{l}\text { Setting Time } \\
\text { by Vicat }\end{array}$ & $\begin{array}{l}\text { Initial } \\
\text { set }\end{array}$ & & & & \\
\hline Needle & \begin{tabular}{|l|} 
Final \\
Set
\end{tabular} & $\min$ & 245 & $\leq 600$ & \\
\hline \multirow[t]{2}{*}{$\begin{array}{l}\text { Compressive } \\
\text { Strength }\end{array}$} & \begin{tabular}{|l} 
For 3 \\
days \\
age
\end{tabular} & $\mathrm{MPa}$ & 27.6 & $\geq 14.7$ & \multirow[t]{2}{*}{$\begin{array}{l}\text { ASTM } \\
\text { C305-06 }\end{array}$} \\
\hline & \begin{tabular}{|l} 
For 7 \\
days \\
age
\end{tabular} & $\mathrm{MPa}$ & 52.2 & $\geq 22.5$ & \\
\hline \multicolumn{2}{|c|}{$\begin{array}{l}\text { Fineness Modulus of } \\
\text { Cement }\end{array}$} & $\mathrm{m}^{2} / \mathrm{kg}$ & 300 & $\geq 230$ & \begin{tabular}{|l|} 
ASTM \\
C204-05
\end{tabular} \\
\hline \multicolumn{2}{|c|}{ Soundness Expansion } & $\mathrm{mm}$ & 2 & $\leq 10$ & \begin{tabular}{|l} 
BS EN \\
$197-01-11$
\end{tabular} \\
\hline
\end{tabular}

Table 2. The chemical test of cement.

\begin{tabular}{|c|c|c|c|c|}
\hline Test required & Unit & Result & \begin{tabular}{|l|}
$\begin{array}{l}\text { Specification } \\
\text { Limits }\end{array}$ \\
\end{tabular} & \begin{tabular}{|l|} 
Standard \\
Specification
\end{tabular} \\
\hline Lost in Ignition & $\%$ & - & $4 \%$ Max & \multirow{13}{*}{$\begin{array}{l}\text { ASTM C114-06 } \\
\text { \& ASTM } \\
\text { C150-07 }\end{array}$} \\
\hline Insoluble residue & $\%$ & - & $1.5 \%$ Max & \\
\hline $\mathrm{SiO}_{2}$ & $\%$ & - & & \\
\hline $\mathrm{CaO}$ & $\%$ & - & & \\
\hline $\mathrm{AL}_{2} \mathrm{O}_{3}$ & $\%$ & 3.39 & & \\
\hline $\mathrm{Fe}_{2} \mathrm{O}_{3}$ & $\%$ & 4.8 & & \\
\hline $\mathrm{MgO}$ & $\%$ & 2.56 & & \\
\hline $\mathrm{SO}_{3}$ & $\%$ & 2.16 & $5 \%$ Max. & \\
\hline $\mathrm{C}_{3} \mathrm{~A}$ & $\%$ & 0.87 & $2.8 \%$ Max. & \\
\hline Chloride & $\%$ & 0.08 & & \\
\hline $\mathrm{C}_{3} \mathrm{~S}$ & $\%$ & - & $\leq 0.1$ & \\
\hline $\mathrm{C}_{2} \mathrm{~S}$ & $\%$ & - & & \\
\hline $\mathrm{C}_{4} \mathrm{AF}$ & $\%$ & - & & \\
\hline
\end{tabular}

Table 3. Grading of fine aggregate.

\begin{tabular}{|l|l|l|l|}
\hline \multirow{2}{*}{ Sieve Size mm } & \multirow{2}{*}{$\%$ Passing } & ASTM Limits \\
\cline { 3 - 5 } & & Lower & Upper \\
\hline 9.50 & 100 & 100 & 100 \\
\hline 4.75 & 96.4 & 95 & 100 \\
\hline 2.36 & 85.3 & 80 & 100 \\
\hline 1.18 & 64.3 & 50 & 85 \\
\hline 0.60 & 45.7 & 25 & 60 \\
\hline 0.30 & 16.2 & 10 & 30 \\
\hline 0.15 & 3.7 & 2 & 10 \\
\hline Fineness modulus & \multicolumn{3}{|l}{} \\
\hline Bulk specific gravity (SSD) & 2.7 & 2.90 \\
\hline
\end{tabular}

\subsection{Specimen Dimension and Details}

The experimental program consisted of casting three full scale reinforced concrete frames with the same dimensions. These dimensions are listed in Table $\mathbf{6}$ and shown in Fig. (1); the column dimension was $300 \times 300 \mathrm{~mm}$; the beam had a width of $300 \mathrm{~mm}$, with $300 \mathrm{~mm}$ dropped below slab; and the slab thickness was $120 \mathrm{~mm}$. The span from the center to the center of the column was $4000 \mathrm{~mm}$ in both directions, and the height of the column was $3000 \mathrm{~mm}$. The concrete strengths were normal at $30 \mathrm{MPa}$ for cubes at the age of 28 days. To understand the effect of concrete age on the mechanical properties of concrete when exposed to fire, the primary variable taken in this study is the ages of concrete when exposed to fire.

Table 4. Grading of coarse aggregate.

\begin{tabular}{|c|c|c|c|}
\hline \multirow{2}{*}{ Sieve Size mm } & \multirow{2}{*}{ \% Passing } & \multicolumn{2}{|c|}{ ASTM Limits } \\
\cline { 3 - 5 } & & Lower & Upper \\
\hline 19 & 100 & 100 & 100 \\
\hline 12.5 & 92.7 & 90 & 100 \\
\hline 9.5 & 62.3 & 40 & 70 \\
\hline 4.75 & 1 & 0 & 15 \\
\hline 2.36 & 0 & 0 & 5 \\
\hline Bulk specific gravity (SSD) & \multicolumn{3}{|c}{2.76} \\
\hline
\end{tabular}

Table 5. Mix proportion.

\begin{tabular}{|l|r|l|l|l|l|}
\hline $\begin{array}{l}\text { Specified } \\
\text { Concrete } \\
\text { Strength } \\
\text { fc'(MPa) }\end{array}$ & $\begin{array}{r}\text { W/C } \\
\mathbf{( \% )}\end{array}$ & $\begin{array}{l}\text { Cement } \\
\left(\mathbf{k g} / \mathbf{m}^{3}\right)\end{array}$ & $\begin{array}{l}\text { Water } \\
\left(\mathbf{k g} / \mathbf{m}^{3}\right)\end{array}$ & $\begin{array}{l}\text { Fine } \\
\text { Aggregate } \\
\left(\mathbf{k g} / \mathbf{m}^{3}\right)\end{array}$ & $\begin{array}{l}\text { Coarse } \\
\text { Aggregate } \\
\left(\mathbf{k g} / \mathbf{m}^{3}\right)\end{array}$ \\
\hline 30 & 0.51 & 356 & 182 & 701 & 1131 \\
\hline
\end{tabular}

Table 6. Specimen with variables.

\begin{tabular}{|c|c|c|}
\hline Frame No. & $\begin{array}{c}\text { *Fc' }^{\text {(MPa) }} \\
\text { FF3 }\end{array}$ & Exposed to Fire at Age (Days) \\
\hline FF5 & 30 & 3 \\
\hline FN & 30 & 5 \\
\hline
\end{tabular}

\subsection{Time-Temperature Curve}

The reinforced concrete frame specimens were cast in a wooden mold. The curing process started after $24 \mathrm{hrs}$ and continued until the concrete age reached three days for FF3 and five days for FF5. Then the wooden mold of the reinforced concrete frame was fired, as shown in Fig. (2). The concrete temperature inside increased after the wooden mold was fired. The changing temperature inside the concrete was measured by inserting K-type thermocouples into the mold before casting and fixed at specified locations, as shown in Fig. (3).

Twelve thermocouples were used in recording temperature inside the reinforced concrete frame. The column height divided into three equal parts, thus, two thermocouples were used at the bottom part, two thermocouples were used at the middle part, while the last two thermocouples were used at the top part of the column. The locations of each of the two thermocouples used in different parts of the column are as follows; the first thermocouple is fixed at a distance equal to the cover of concrete while the second thermocouple is fixed at the center of the column section. Similarly, three thermocouples were used at the center of beam span and distributed as 

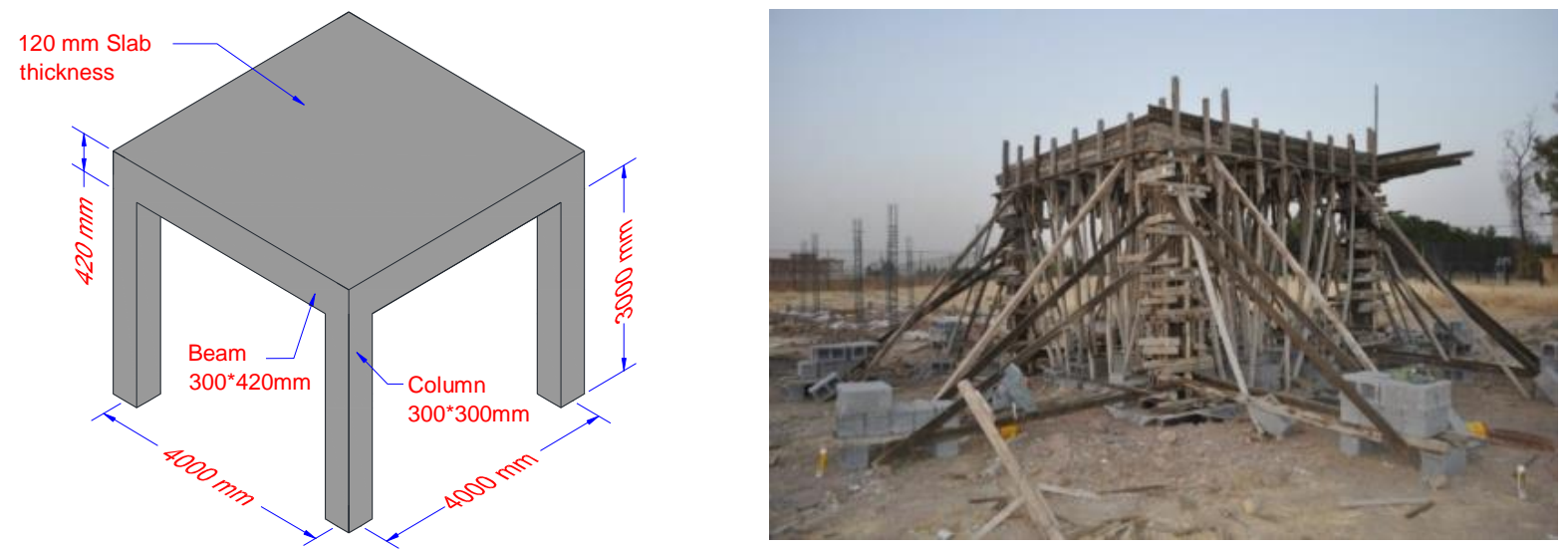

Fig. (1). Dimensions of frame sample.

follows: the first and third were inserted at a distance equal to concrete cover from inside and outsides of beam cross-section while the second was inserted at the center of beam section. Finally, the two thermocouples were used in the center of the slab and at different heights, one at the top and the second at the bottom of the slab.

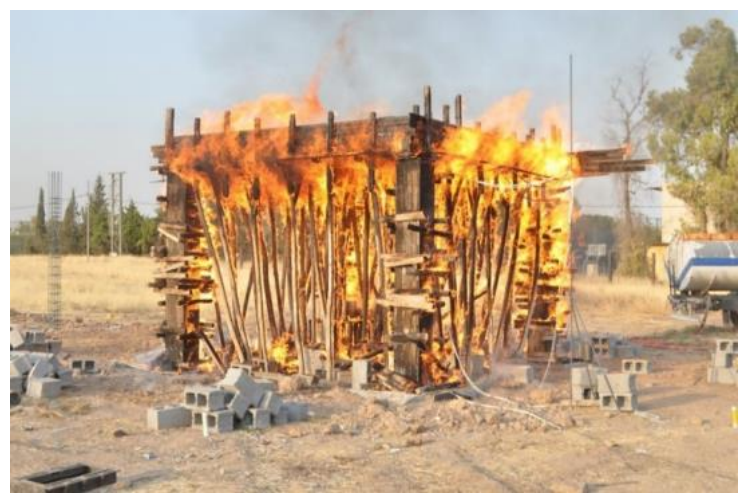

Fig. (2). Reinforced concrete frame exposed to fire.

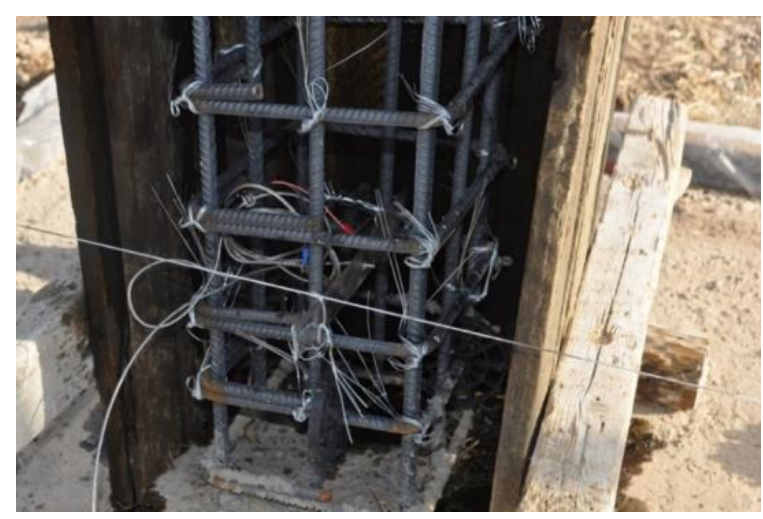

Fig. (3). Insertion of a thermocouple.

After all recorded temperatures were collected, the average time-temperature curve was drawn, as shown in Fig. (4). Thus, the temperature increased with time. Generally, in the first 10 minutes, the temperature increased significantly and reached $400{ }^{\circ} \mathrm{C}$ because of the fire in the ignition step. The temperature then decreased to $200{ }^{\circ} \mathrm{C}$ on average until the end of the firing process.

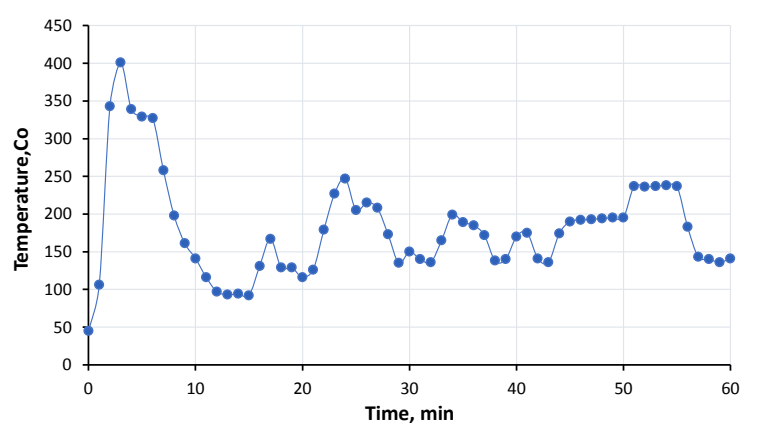

Fig. (4). Time-temperature relationship.

\subsection{Ultrasonic Pulse Velocity Test (UPV)}

The ultrasonic pulse velocity test is a very common nondestructive test. It is quick and easy to perform. For more than 60 years, this test method has been used to evaluate concrete quality [19]. This is a successful way of quickly checking the uniformity of the concrete in various parts of the structure, or various structures or indicating the existence of voids or internal cracks and identifying changes in the structural properties of the concrete [20 - 22]. The ultrasonic pulse velocity can also be used to monitor the development of compression strength and to evaluate structural integrity [23]. UPV test is prescribed in ASTM C597 [24].

The test device is easy to operate and includes a pulse generator, transmitter head, receiving head, and a unit of measurement. The system at the receiving head is used to measure the time of arrival for a compression wave, i.e. the wave that propagates most rapidly in concrete. The concrete surface must be smooth, with the transmitter head and the receiving head in good contact with the concrete, in order to prevent measurement errors. Constant pressure is achieved through good contact between the heads and the concrete surface, and the use of 
a thin layer of contact gel between these heads. As shown in Fig. (5), the heads are arranged in three distinct configurations: the direct method with an angle of 180 degrees between the heads; the semi-direct method with an angle of 90 degrees between the heads; and the indirect surface method with an angle of 0 degrees between the heads. The direct method is preferred because the maximum pulse energy is received at the receiving head, but due to the geometry of the structure, this configuration is in many cases impossible. The concentrations of reinforcement can be avoided using the semi-direct method. The indirect method does not provide the same good values as the direct and semi-direct methods; however, it can be used to assess the thickness of the poor-quality layer [19].
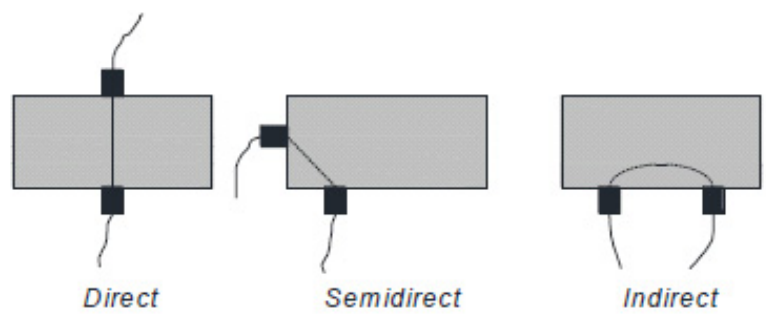

Fig. (5). Different configurations for measurements of the ultrasonic pulse velocity.

To evaluate the strength of the reinforced concrete frames after firing and to cover the reading of all the elements of reinforced concrete frames by using the UPV test, the frames were divided into three elements: columns, beams, and slabs. The reading was taken at the top, mid-height, and bottom of the columns and in the two-axis direction. While in the beams, the readings were taken on the right side, left side, and the midspan. Finally, in the slabs, the readings were taken at the center and the two corners.

\subsection{Core Tests}

The core test is the most direct technique for assessing the compressive strength of concrete in existing structures. Many standards and guidelines are available to guide engineers and investigators in real practice. The widely used ones are EN 12504-1 [25], EN 13791 [26] in Europe and ACI 214.4R [27], ASTM C42 [28] in the US. The evaluation methodology for determining concrete strength using cores can be summarized in the following main steps: planning an investigation program, drilling cores, testing cores, and interpreting core strengths. The tests on core samples provide direct evidence of the residual compressive strength and temperature to which the concrete member is subjected to while under fire [29]. Through compression tests carried out on cores extracted from structural elements, it is thus clearly important to estimate the compressive strength of concrete in situ correctly [30].

The drilling samples from reinforced concrete frames were collected from three different elements. The three core samples were collected from each of the columns, beams, and slab, as shown in Fig. (6).

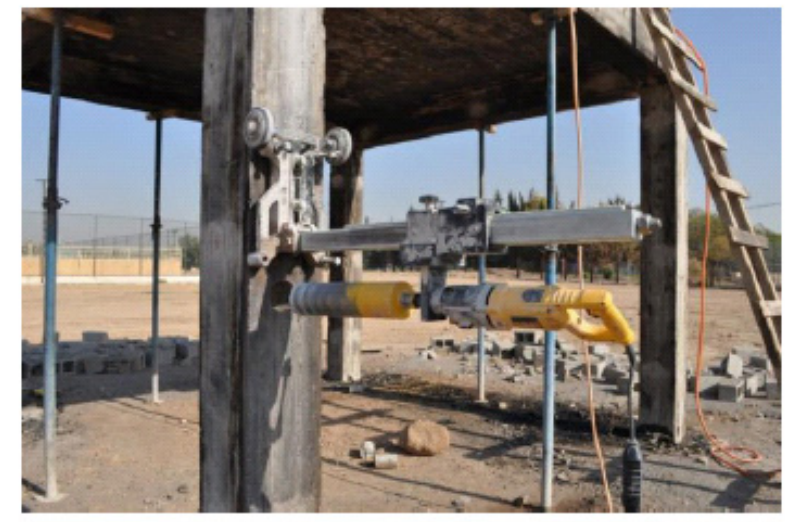

Fig. (6). Core location in reinforced concrete frame.

\section{RESULTS AND DISCUSSION}

All the readings of UPV and crushing compressive strength of core samples were plotted to generate different relations. The following are the various results and plots:

\subsection{UPV Test}

Several models have been used to estimate concrete strength using UPV [31 - 36]. Among these models, the one proposed by Al-Nu'man et al. [37] was selected because it is the best and the most reliable equation for estimating the compressive strength of concrete by using UPV.

$$
\mathrm{fcu}=1.03 \exp (0.87 \mathrm{v})
$$

where $\mathrm{v}$ is the velocity of in $(\mathrm{m} / \mathrm{sec})$

The results of the application of Eq. (1) on the velocity readings of the UPV test of different elements of reinforced concrete frames to estimate compressive strength concrete are shown in Table 7. The effect of natural fire on the compressive strength of concrete can be illustrated by comparing the compressive strength at different ages of various elements, as shown in Fig. (7). The bar graph presents the compressive strength results of the slab, beam, and column elements in concrete frames FF3, FF5, and FN. Generally, natural fire exposure in all the elements of frame FF3, in which the age of concrete was three days, the compressive strength was reduced by $52 \%$ when compared to frame FN. By contrast, in frame FF5, in which the age of concrete was five days, the compressive strength was reduced by $50 \%$ when compared to frame FN. Overall, the difference in the reduction of compressive strength between FF3 and FF5 was minimal because they have almost similar concrete ages.

For more details, in the slab element of frame FF3, compressive strength was decreased by $24 \%$ when exposed to fire at an age of 3 days. By contrast, with 5 days of fire exposure (FF5), its strength decreased by $14 \%$ in comparison to the frame FN that was not exposed to fire FN. Thus, the effect of burning and removing the wooden shore that supports the slab formwork on the strength of slab concrete was more apparent in the earlier ages than in the later ones. The strength of the beam elements exposed to fire for 3 days (FF3) decreased by $27 \%$. By contrast, the strength of the beam elements 
exposed to fire for 5 days (FF5) decreased by $19 \%$ in comparison to the frame FN that was not exposed to the fire. Finally, for column elements with less fire exposure, their strength reduced by $22 \%$ after 3 days of concreting FF3, whereas after 5 days (FF5), the decrease was $7 \%$ in comparison to the frame FN that was not exposed to the fire.

Table 7. The compressive strength of concrete elements according to the UPV test.

\begin{tabular}{|c|c|c|c|}
\hline Frame No. & Slab (MPa) & Beam (MPa) & Column (MPa) \\
\hline FF3 & 17.4 & 26.4 & 22.8 \\
\hline FF5 & 18.6 & 29.1 & 27.0 \\
\hline FN & 20.6 & 36.0 & 29.2 \\
\hline
\end{tabular}

\subsection{Core Test}

Taking core specimens from concrete suspected of being damaged by fire is common [38]. In each reinforced concrete frame, FF3 and FF5 core samples were taken after being exposed to fire. By contrast, in frame FN, core samples were taken without exposing the structure to fire. The core samples were prepared by cutting the end parts and then creating cupping for them. All necessary dimensions and information were then recorded. To study the effect of fire on concrete at an early age, all the core samples were tested to check their compressive strength. The results are shown in Table 8 and Fig. (8).
Table 8. The compressive strength of concrete elements according to the core test.

\begin{tabular}{|c|c|c|c|}
\hline Frame No. & Slab (MPa) & Beam (MPa) & Column (MPa) \\
\hline FF3 & 26.4 & 25.0 & 24.7 \\
\hline FF5 & 26.2 & 35.5 & 36.5 \\
\hline FN & 36.4 & 38.2 & 38.3 \\
\hline
\end{tabular}

Fig. (8) presents a bar graph that shows the compressive strength of the core samples taken from the slab, beam, and column elements in different frame structures. Generally, the compressive strength of the core samples collected from frames exposed to the fire was lower than that of the frames that were not exposed to the fire. The reduction in compressive strength of core samples in the slab element showed that FF3 and FF5 have the same value, which was $28 \%$ in comparison to the FN which was not exposed to the fire. After the beams were exposed to fires, the compressive strength values of the core samples in FF3 were reduced by $35 \%$, whereas the compressive strength value of the core sample was reduced by $7 \%$ in FF5 when compared to FN. The compressive strength of the core samples in the column elements was reduced by $35 \%$ and 5\% for FF3 and FF5, respectively, when exposed to fires. The previous comparisons in compressive strength of core samples of frames in different elements show that the compressive strength of the core samples is more affected by the fire at an earlier age than older.

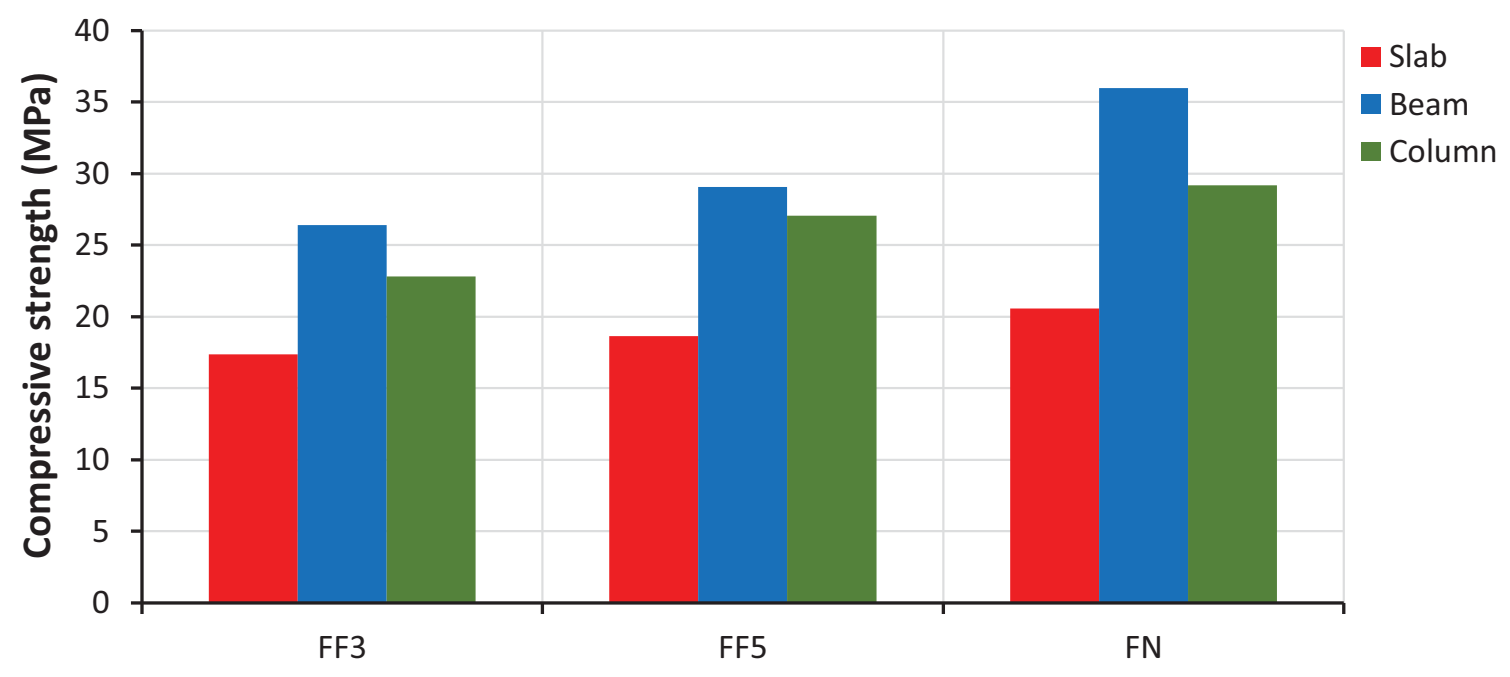

Frame No.

Fig. (7). The compressive strength of concrete elements according to the UPV test. 


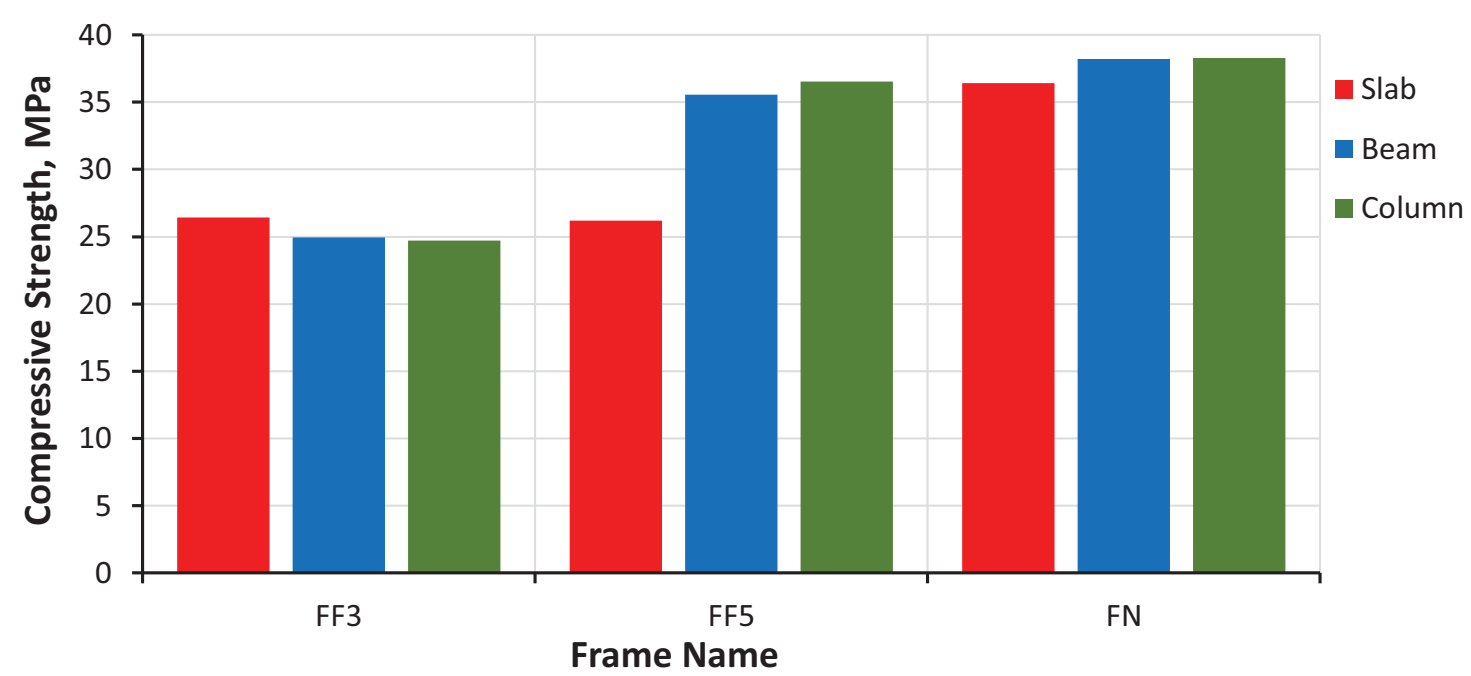

Fig. (8). The compressive strength of concrete elements according to the core test.

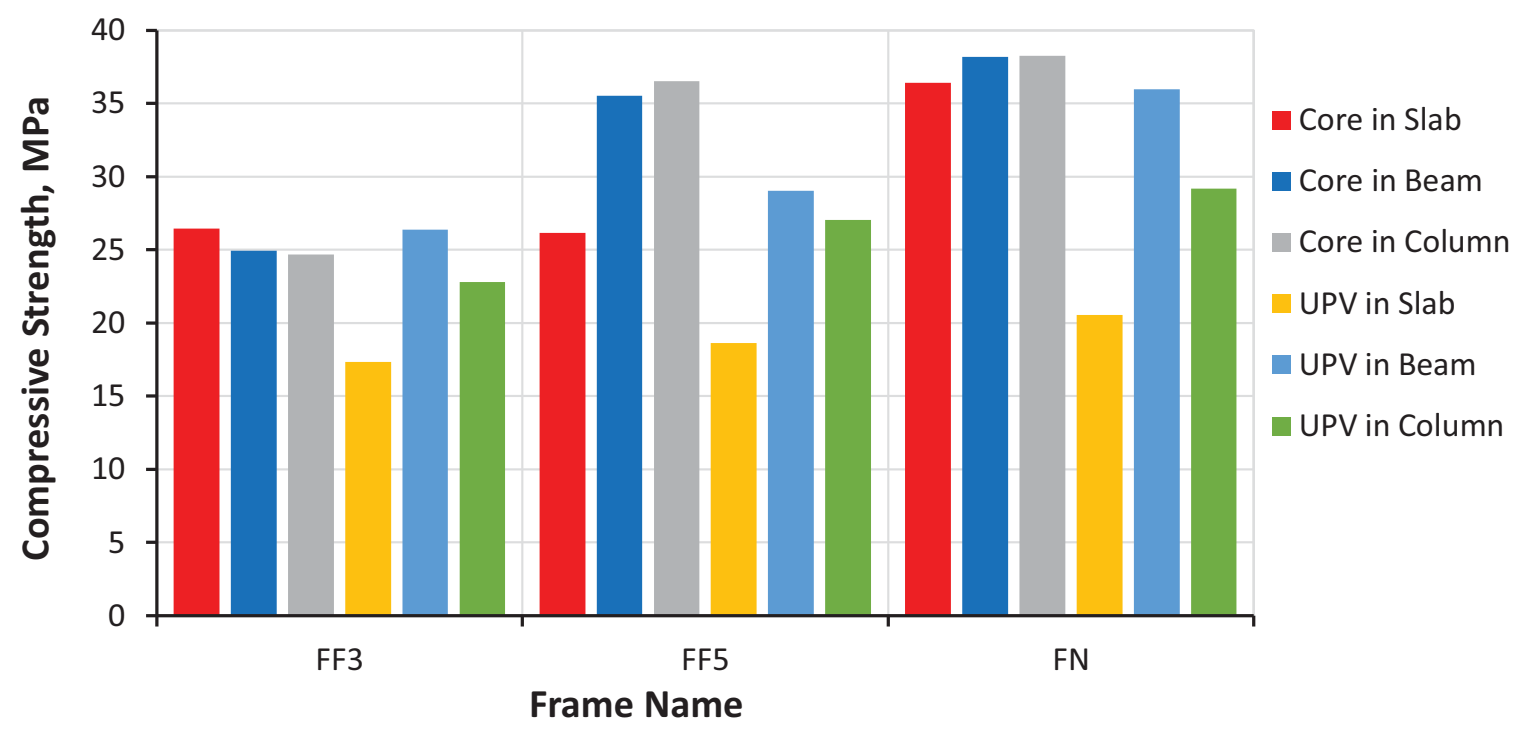

Fig. (9). Comparison between the UPV and core tests.

\subsection{Comparison Between the UPV and Core Tests}

A structural engineer cannot take cores from structures in every location and situation. A comparison was performed to show the varying results of the UPV test and the core test.

Fig. (9) presents the compressive strength comparison between the core test and the UPV test for frames FF3, FF5, and FN in the slab, beam, and column elements. Generally, the UPV test takes further precaution and presents fewer values, whereas the core test presents higher values. The comparison between the results of elements shows that in the slab, the strength values obtained by the UPV test were smaller by about $57.4 \%$ than those obtained by the core test. In the beam, the strength values obtained by the UPV test were $10 \%$ smaller than those obtained by the core test. Finally, in the column, the strength values obtained by the UPV test were $26 \%$ smaller than those obtained by the core test.

\section{CONCLUSION}

The concrete quality of structural elements under natural fire at an early age was evaluated using nondestructive and destructive methods. Based on the observation and analysis of test results, the following conclusions were drawn:

1-In general, the frame that was exposed early to natural fire was more affected than the frame exposed later, and its compressive strength was reduced to about $33 \%$ because of the concrete in the initial hydration process.

2-The slab elements of frame FF3 and FF5 between all elements of the structural frame had the same effect from the natural fire in comparison with other elements because the fire moves upward towards the slab and the slab is wider, therefore the effect was similar.

3-In general, if a fire accident happened in any reinforced concrete structure at an early age, then the 
structure did not get affected by the fire because the time was short and fire exposure was not high. 4-Overall, the results of the UPV test are close to those of the core test. Hence, the core sample cannot be collected from any location due to the structure after fire exposure. Hence, it can depend on the results of the UPV test.

\section{CONSENT FOR PUBLICATION}

Not applicable.

\section{AVAILABILITY OF DATA AND MATERIALS}

The authors confirm that the data supporting the findings of this study are available within the article.

\section{FUNDING}

None.

\section{CONFLICT OF INTEREST}

The authors declare no conflict of interest, financial or otherwise.

\section{ACKNOWLEDGEMENTS}

We sincerely acknowledge the College of Engineering in Salahaddin University-Erbil for allowing us to do this research. We are also thankful to the reviewers for their suggestions in improving the quality of the article.

\section{REFERENCES}

[1] M.M. Bikhiet, N.F. El-Shafey, and H.M. El-Hashimy, "Behavior of reinforced concrete short columns exposed to fire", Alexandria Eng. J., vol. 53, pp. 643-653, 2014. [http://dx.doi.org/10.1016/j.aej.2014.03.011]

[2] L. Lu, G. Yuan, Q. Shu, Z. Huang, C. Zhong, and B. Xu, "Bond behaviour between early age concrete and steel bar subjected to cyclic loading after fire", Fire Saf. J., vol. 105, pp. 129-143, 2019. [http://dx.doi.org/10.1016/j.firesaf.2019.02.012]

[3] Q. Keli, D. Yajuan, and G. Lixia, "Study on the tensile creep model of the admixture of early-age concrete and application simulation", Open Civ. Eng. J., vol. 9, pp. 1002-1006, 2015. [http://dx.doi.org/10.2174/1874149501509011002]

[4] G. Khoury, "Compressive strength of concrete at high temperatures: A reassessment", Mag. Concr. Res., vol. 44, pp. 291-309, 1992. [http://dx.doi.org/10.1680/macr.1992.44.161.291]

[5] U. Schneider, "Concrete at high temperatures-a general review", Fire Saf. J., vol. 13, pp. 55-68, 1988 .

[http://dx.doi.org/10.1016/0379-7112(88)90033-1]

[6] J. Xiao, and G. König, "Study on concrete at high temperature in China-an overview", Fire Saf. J., vol. 39, pp. 89-103, 2004. [http://dx.doi.org/10.1016/S0379-7112(03)00093-6]

[7] G. Khoury, Y. Anderberg, K. Both, J. Fellinger, N. Høj, and C. Majorana, "Fib bulletin 38: fire design of concrete structures-materials, structures and modelling, state-of-the art report", In: Federation internationale du beton, Lausanne, Switzerland, 2007

[8] L. Bisby, J. Gales, and C. Maluk, "A contemporary review of largescale non-standard structural fire testing", Fire Sci. Rev., vol. 2, p. 1, 2013.

[http://dx.doi.org/10.1186/2193-0414-2-1]

[9] R.D. Hooton, A. Di Maio, G. Giaccio, and R. Zerbino, "Nondestructive tests for the evaluation of concrete exposed to high temperatures", Cem. Concr. Aggreg., vol. 24, p. 11225, 2002. [http://dx.doi.org/10.1520/CCA10530J]

[10] L.D. Kirchhof, A. Lorenzi, and L.C.P Silva Filho, "Assessment of concrete residual strength at high temperatures using ultrasonic pulse velocity", The e-J Nondestr. Test., vol. 20, no. 7, pp. 1-10, 2015.

[11] B. Chen, C. Li, and L. Chen, "Experimental study of mechanical properties of normal-strength concrete exposed to high temperatures at an early age", Fire Saf. J., vol. 44, pp. 997-1002, 2009.

[http://dx.doi.org/10.1016/j.firesaf.2009.06.007]

[12] ASTM E119 - 19 Materials, Standard methods of fire tests of building construction and materials, 2007.

[13] F. Wald, L. Simões da Silva, D.B. Moore, T. Lennon, M. Chladná, and A. Santiago, "Experimental behaviour of a steel structure under natural fire", Fire Saf. J., vol. 41, pp. 509-522, 2006.

[http://dx.doi.org/10.1016/j.firesaf.2006.05.006]

[14] R. Pucinotti, "Reinforced concrete structure: Non destructive in situ strength assessment of concrete", Constr. Build. Mater., vol. 75, pp. 331-341, 2015.

[http://dx.doi.org/10.1016/j.conbuildmat.2014.11.023]

[15] P.K. Mehta, and P. J. Monteiro, Concrete: microstructure, properties, and materials, McGraw-Hill Education: Chicago, USA, 2006.

[16] M. Santhanam, and R. Gettu, "Chapter 13: Early-age properties of concrete", In: ICE manual of Construction Materials: Volume I: Fundamentals and theory; Concrete; Asphalts in road construction; Masonry, Thomas Telford Ltd, 2009, pp. 135-144.

[17] International Federation for Structural Concrete Working Party, "Fire design of concrete structures-materials, structures and modeling", In: Lausanne: International Federation of Concrete (FIB), 2007.

[18] A.M. Neville, Properties of concrete, Fifth Edition ed.: Pearson Education India, 2011.

[19] J. Albrektsson, M. Flansbjer, J-E. Lindqvist, and R. Jansson, "Assessment of concrete structures after fire", Brandforsk project number, pp. 301-091, 2011.

[20] D.H. Nguyen, V.T. Dao, and P. Lura, "Tensile properties of concrete at very early ages", Constr. Build. Mater., vol. 134, pp. 563-573, 2017. [http://dx.doi.org/10.1016/j.conbuildmat.2016.12.169]

[21] Y. Pan, A. Prado, R. Porras, O.M. Hafez, and J.E. Bolander, "Lattice modeling of early-age behavior of structural concrete", Materials (Basel), vol. 10, no. 3, p. 231, 2017.

[http://dx.doi.org/10.3390/ma10030231] [PMID: 28772590]

[22] Q. Shu, L. Lu, G. Yuan, C. Zhong, and B. Xu, "Experimental investigation on the mechanical properties of early-age concrete after heating up to $550^{\circ} \mathrm{C}^{\prime \prime}$, Eur. J. Environ. Civ. Eng., pp. 1-15, 2019. [http://dx.doi.org/10.1080/19648189.2019.1578269]

[23] B. Mohammed, Z. Syed, V. Khed, and M. Qasim, "Evaluation of nano-silica modified ECC based on ultrasonic pulse velocity and rebound hammer", The Open Civ. Eng. J., vol. 11, pp. 638-649, 2017.

[24] ASTM, Standard Test Method for Pulse Velocity Through Concrete, ed. West Conshohocken ,PA,: United States, 2009.

[25] B. BSI, BS EN 12504-1: 2009 Testing concrete in structures. Cored specimens. Taking, examining and testing in compression., BSI: London, UK, 2009.

[26] E. 13791, "Assessment of in-situ compressive strength in structures and precast concrete components", In: European Standard, ed. CEN, Brussels, 2007.

[27] A. C. I. (ACI), Guide for obtaining cores and interpreting compressive strength results, ed. 38800 Country Club Drive Farmington Hills: MI 48331 U.S.A, 2010.

[28] ASTM, Standard test method for obtaining and testing drilled cores and sawed beams of concrete., West Conshohocken: PA, United States, 2013.

[29] S. Iffat, and B. Bose, "A review on concrete structures in fire", Int $J$ Civ, Environ., Struct., Constr. Archit. Eng., vol. 2, pp. 123-128, 2016.

[30] R. Pucinotti, "Assessment of in situ characteristic concrete strength", Constr. Build. Mater., vol. 44, pp. 63-73, 2013. [http://dx.doi.org/10.1016/j.conbuildmat.2013.02.041]

[31] J. Agunwamba, and T. Adagba, "A comparative analysis of the rebound hammer and ultrasonic pulse velocity in testing concrete", Niger. J. Tech., vol. 31, pp. 31-39, 2012.

[32] D. Breysse, "Nondestructive evaluation of concrete strength: An historical review and a new perspective by combining NDT methods", Constr. Build. Mater., vol. 33, pp. 139-163, 2012.

[http://dx.doi.org/10.1016/j.conbuildmat.2011.12.103]

[33] S. Hannachi, and M.N. Guetteche, "Application of the combined method for evaluating the compressive strength of concrete on site", Open J. Civil Eng., vol. 02, pp. 16-21, 2012. [http://dx.doi.org/10.4236/ojce.2012.21003]

[34] R. Latif Al-Mufti, and A.N. Fried, "The early age non-destructive testing of concrete made with recycled concrete aggregate", Constr. Build. Mater., vol. 37, pp. 379-386, 2012.

[http://dx.doi.org/10.1016/j.conbuildmat.2012.07.058]

[35] A. Jain, A. Kathuria, A. Kumar, Y. Verma, and K. Murari, "Combined use of non-destructive tests for assessment of strength of concrete in 
structure", Procedia Eng., vol. 54, pp. 241-251, 2013

[http://dx.doi.org/10.1016/j.proeng.2013.03.022]

[36] D.A. Jaf, D.K. Bzeni, and Y.Z. Dinkha, "Strength estimation of concrete produced in kurdistan region using combined method", ZANCO J. Pure Applied Sci, vol. 28, no. 2, 2016.
[37] B.S. Al-Nu'man, B.R. Aziz, S.A. Abdulla, and S.E. Khaleel, "Compressive strength formula for concrete using ultrasonic pulse velocity", Int. J. Eng. Trends Tech., vol. 26, pp. 8-13, 2015. [IJETT].

[38] M.Y. Chew, "The assessment of fire damaged concrete", Build Environ., vol. 28, pp. 97-102, 1993.

[http://dx.doi.org/10.1016/0360-1323(93)90010-Z]

\section{(C) 2019 Omer and Jaf}

This is an open access article distributed under the terms of the Creative Commons Attribution 4.0 International Public License (CC-BY 4.0), a copy of which is available at: https://creativecommons.org/licenses/by/4.0/legalcode. This license permits unrestricted use, distribution, and reproduction in any medium, provided the original author and source are credited. 